Research article

\title{
ASSESSMENT OF THE WELFARE OF EXTENSIVELY MANAGED AUTOCHTONOUS SHEEP BREED VLASICKA ZACKEL USING ANIMAL-BASED MEASUREMENTS
}

\author{
NENADOVIĆ Katarina ${ }^{1 *}$, KARAĆ Petar ${ }^{2}$, VUČINIĆ Marijana ${ }^{1}$, \\ TEODOROVIĆ Radislava ${ }^{1}$, ŽIVANOV Dragan ${ }^{3}$, TRAILOVIĆ Ružica ${ }^{4}$, \\ BECKEI Zsolt ${ }^{4}$, JANKOVIĆ Ljiljana ${ }^{1}$
}

\begin{abstract}
${ }^{1}$ Department of Animal Hygiene, Faculty of Veterinary Medicine, University of Belgrade, Serbia; ${ }^{2}$ Faculty of Veterinary Medicine, University of Belgrade, Serbia; ${ }^{3}$ Department of General Education, Faculty of Veterinary Medicine, University of Belgrade, Serbia; ${ }^{4}$ Department for Animal Breeding, Faculty of Veterinary Medicine, University of Belgrade, Serbia
\end{abstract}

(Received 21 June 2019, Accepted 06 February 2020)

\begin{abstract}
In the Balkan region, the state of sheep welfare is little known. In this context, the assessment of sheep welfare is important for the identification of health and behavioral problems that affect these animals, along with the deficiencies present in the environment. The study was conducted during the winter season on a farm of 220 autochthonous breed Vlašićka Zackel sheep reared in extensive systems on the mountain regions of Bosnia and Herzegovina. A total of 65 ewes, aged 2-4 years, were observed. The welfare assessment was performed according to the AWIN protocol for sheep. The authors found the following issues: dry ewes were significantly fat $(\mathrm{p}<0.001)$ in regard to pregnant and lactation ewes; $42.11 \%$ of pregnant ewes were thin while $31.25 \%$ of dry ewes were fat; most of the assessed animals $(78.46 \%)$ had dry or damp, slightly soiled fleece; $32.31 \%$ of animals had lesions on face/muzzle while ocular discharge, respiratory problems, mild mastitis and minor lameness were present in $16.92 \%, 4.62 \%, 15.38 \%$ and $7.69 \%$ sheep, respectively. All animals showed a negative relationship with humans. Using this methodology, the welfare problems in animals may be detected, and thus certain segments in the production cycle may be improved. The on-farm welfare assessment is highly recommended for emphasizing the key points in improving sheep welfare in Balkan countries.
\end{abstract}

Key words: animal welfare, AWIN, ewes, animal-based measurements

\section{INTRODUCTION}

Animal-based measures usually have been used as an early warning for animals with deteriorating welfare, as well as, for immediate recognizing of improvements in welfare to maximize benefits [1].

\footnotetext{
*Corresponding author: e-mail: katarinar@vet.bg.ac.rs
} 
There are currently over 1.2 billion sheep in the world [2] which are primarily bred for milk, meat and wool production. The majority of these animals are managed under extensive conditions, where at least a portion of their life is spent outdoors on grazing land with minimal daily interactions with humans $[3,4]$. Sheep in extensive environments may face a range of compromises to their well being, but principally these relate to variations in climate and the availability of adequate or suitable nutrition and attack of predators [5]. In assessing sheep welfare, identifying the risk of experiencing poor welfare, is important as part of welfare assessment, as well as indicators of actual welfare compromise. For example, poor fleece coverage can be a risk factor for experiencing thermal discomfort if the weather is bad [6].

In Bosnia and Hercegovina, the most common autochthonous sheep breed is the Vlašićka Zackel. Its name comes from Mountain Vlašić near the town of Travnik where the breed was developed. Travnik Zackel sheep („pramenka”) is a very endurable breed that is easily adapted to severe weather conditions, lower quality feed and being more resistant to local parasites and diseases [7]. This breed of sheep is characterized by extremely high yield and quality of milk from which is made famous Travnik cheese.

Since welfare is a condition of the animal, animal-based measures are likely to be the most direct reflection of its welfare state. This paper aims to present the first outcomes of data collected in a sample of extensively reared autochthonous sheep of the breed „Vlašićka pramenka” on fenced paddock using AWIN welfare assessment protocol for sheep (animal-based indicators) and to identify the welfare problems that affect these animals.

\section{MATERIAL AND METHODS}

\section{Management and Animals}

The study was conducted in December 2018, on a farm of 220 autochthonous sheep breed Vlašićka Zackel reared in the extensive system. The farm is situated in the hilly mountainous region of Bosnia and Herzegovina (Figure 1). The hills range from 600 $\mathrm{m}$ up to $1.300 \mathrm{~m}$ above sea level, with natural pasture. All year round, the flock of ewes grazes in fenced paddocks where the water is provided from a natural spring. Shelter from varying climatic extremes is provided by trees, shrubs and other vegetation. During the winter, only ewes and newly-born lambs stay in a barn for a maximum of three weeks. All other sheep are stay outdoor in a fenced paddock. No infectious diseases were contracted, no known problems occurred in mineral deficiencies and there were no extreme cases of parasitism. The advice of farm consultants and veterinarians was also considered.

A total number of sheep on the farm include 217 ewes and 3 rams. We observed 65 ewes, aged 2-4 years (30 ewes in the lactation period, 19 pregnant ewes and 16 ewes in the dry period). The ewe sample size was selected based on a power calculation assuming $50 \%$ prevalence of the trait under observation (the proportion requiring the 
greatest sample size when observing binomial traits), a 95\% confidence level and a precision of $\pm 10 \%$. This number was supported by the AWIN sheep protocol which recommends a sample of 65 animals when the farm size is between 200-224 breeding ewes [8].

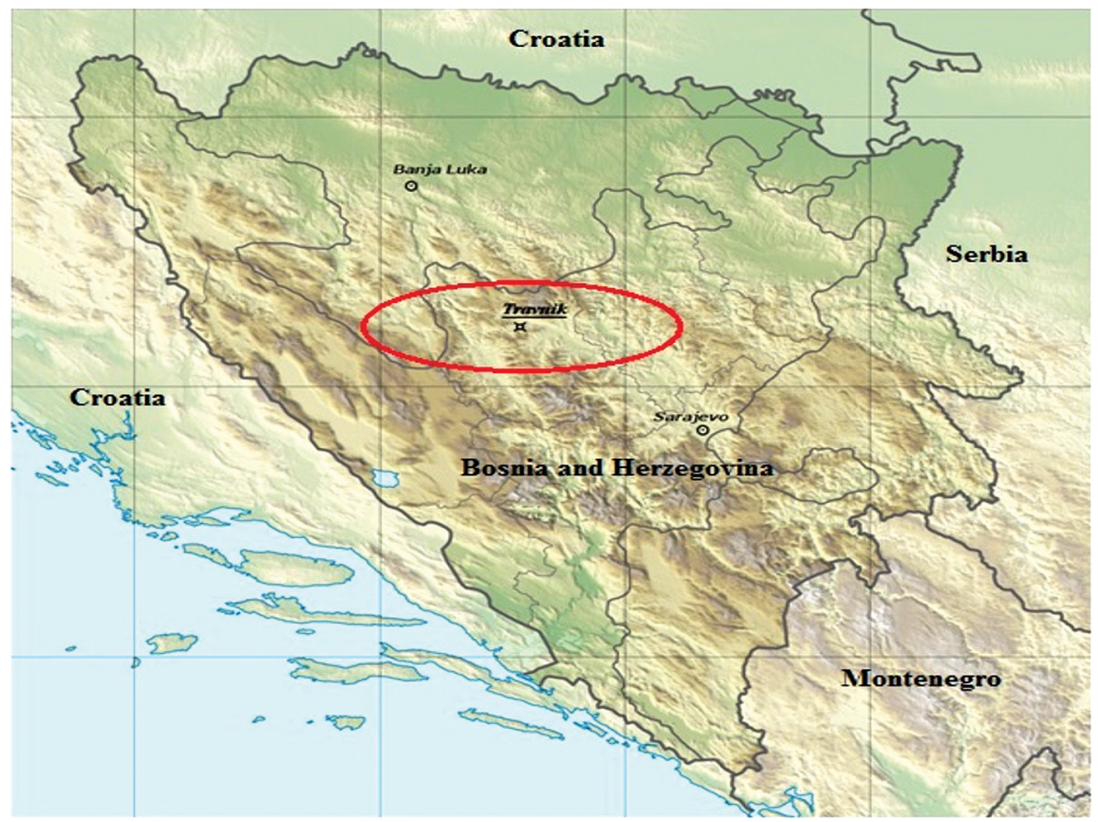

Figure 1. Graphic presentation of the Travnik area

\section{Methods}

The assessment of the ewes was conducted between $9 \mathrm{~h}$ and $16 \mathrm{~h}$ using the AWIN welfare assessment protocol for sheep [8] which is grouped into 12 welfare criteria based on principles of good feeding, good housing, good health and appropriate behavior (Table 1). In this study, we used only animal-based measures: body condition, fleece cleanliness, panting, body and head lesions, leg injuries, lameness, fecal soiling, ocular discharge, mucosa color, mastitis and udder lesions, respiratory quality, fleece quality, tail length, social withdrawal, stereotypy, excessive itching and human animal relationship (Table 1). The approximate time needed to assess an individual ewe is 2 min. We have tested negative relationship with humans according to AWIN protocol. The farmer approached the sheep in the normal manner, on foot. We were far away as is feasible to record the data without disturbing the sheep [8]. 
Table 1. The AWIN indicators for sheep, for different welfare principles and criteria

\begin{tabular}{|c|c|c|}
\hline $\begin{array}{l}\text { Welfare } \\
\text { principles }\end{array}$ & $\begin{array}{l}\text { Welfare } \\
\text { criteria }\end{array}$ & $\begin{array}{l}\text { Welfare } \\
\text { indicators }\end{array}$ \\
\hline \multirow{3}{*}{$\begin{array}{l}\text { Good } \\
\text { feeding }\end{array}$} & \multirow{2}{*}{ Appropriate nutrition } & Body Condition ABM \\
\hline & & Score lamb mortality ${ }^{\mathrm{RBM}}$ \\
\hline & Absence of prolonged thirst & Water availability \\
\hline \multirow{5}{*}{$\begin{array}{l}\text { Good } \\
\text { housing }\end{array}$} & Comfort around resting & Fleece cleanliness ${ }^{\text {ABM }}$ \\
\hline & \multirow[b]{2}{*}{ Thermal comfort } & Panting ABM \\
\hline & & $\begin{array}{l}\text { Access to shade/shelter (outdoors } \\
\text { only) RBM }\end{array}$ \\
\hline & \multirow[b]{2}{*}{ Ease of movement } & Stocking density (housed animals only) ${ }^{\mathrm{RBM}}$ \\
\hline & & $\begin{array}{l}\text { Hoof overgrowth(housed animals } \\
\text { only) } \mathrm{ABM}\end{array}$ \\
\hline \multirow{10}{*}{$\begin{array}{l}\text { Good } \\
\text { health }\end{array}$} & \multirow{2}{*}{ Absence of injuries } & Body and head lesions $\mathrm{ABM}$ \\
\hline & & Leg injuries $\mathrm{ABM}$ \\
\hline & \multirow{7}{*}{ Absence of disease } & Lameness ABM \\
\hline & & Fecal soiling ABM \\
\hline & & Ocular discharge $\mathrm{ABM}$ \\
\hline & & Mucosa color ${ }^{\mathrm{ABM}}$ \\
\hline & & $\begin{array}{l}\text { Mastitis and udder lesions }{ }^{A B M} \\
\text { (lactating ewes only) }\end{array}$ \\
\hline & & Respiratory quality ${ }^{A B M}$ \\
\hline & & Fleece quality $\mathrm{ABM}$ \\
\hline & $\begin{array}{l}\text { Absence of pain and pain induced } \\
\text { by management procedures }\end{array}$ & Tail length ABM \\
\hline \multirow{5}{*}{$\begin{array}{l}\text { Appropriate } \\
\text { behavior }\end{array}$} & Expression of social behavior & Social withdrawal ABM \\
\hline & \multirow{2}{*}{ Expression of other behaviors } & Stereotypy ABM \\
\hline & & Excessive itching ${ }^{\mathrm{ABM}}$ \\
\hline & Good human animal relationship & Familiar human approach test ${ }^{A B M}$ \\
\hline & Positive emotional state & Qualitative Behavior Assessment ${ }^{\mathrm{ABM}}$ \\
\hline
\end{tabular}

ABM - animal - based measures; RBM - resource - based measures

\section{Statistical Analysis}

Data were processed with the Graph Pad Prism statistics software. Chi-square $(\chi 2)$ test was used for determining statistical significance of body condition differences between different physiological statuses of ewes. 


\section{RESULTS}

Results regarding indicators for "good feeding" are reported in Table 2. In all three subcategories of ewes, condition of most of the animals was scored as „good“. Thin animals were noticed mostly among pregnant ewes. Dry ewes were significantly fat $(\mathrm{p}<0.001)$ in regard to pregnant and lactation ewes (Table 2).

Table 2. Results of "good feeding"

\begin{tabular}{|c|c|c|c|c|c|c|c|c|c|}
\hline \multirow{4}{*}{\multicolumn{2}{|c|}{ Welfare Indicator }} & \multicolumn{8}{|c|}{ Sheep at different physiological status } \\
\hline & & \multirow{2}{*}{\multicolumn{2}{|c|}{$\begin{array}{l}\text { Lactation ewes } \\
\qquad(\mathrm{n}=30)\end{array}$}} & \multirow{2}{*}{\multicolumn{2}{|c|}{$\begin{array}{c}\begin{array}{c}\text { Pregnant } \\
\text { ewes }\end{array} \\
(n=19)\end{array}$}} & \multirow{2}{*}{\multicolumn{2}{|c|}{$\begin{array}{c}\text { Dry ewes } \\
\qquad(n=16)\end{array}$}} & \multirow{3}{*}{$\chi^{2}$} & \multirow{3}{*}{$\mathrm{p}$} \\
\hline & & & & & & & & & \\
\hline & & $\mathbf{N}$ & $\%$ & $\mathbf{N}$ & $\%$ & $\mathbf{N}$ & $\%$ & & \\
\hline \multirow{3}{*}{$\begin{array}{l}\text { Body } \\
\text { Condition }\end{array}$} & Thin & 12 & 40 & 8 & 42.11 & 3 & 18.75 & 2.59 & 0.27 \\
\hline & Good & 17 & 56.66 & 11 & 57.89 & 8 & 50 & 0.25 & 0.88 \\
\hline & Fat & 1 & 3.33 & 0 & 0 & 5 & 31.25 & 12.43 & $0.00^{* * *}$ \\
\hline
\end{tabular}

$* * *-\mathrm{p}<0.001$

In Table 3 are reported the results regarding indicators for "good housing". Based on the results, no sheep presented any signs of thermal stress. Most of the animals showed dry or slightly damp fleece $78.46 \%$ (51/65).

Table 3. Results of "good housing"

\begin{tabular}{llcc}
\hline \multirow{2}{*}{ Welfare Indicator } & \multicolumn{2}{c}{ Sheps (n=65) } \\
\cline { 3 - 4 } Panting & Yes & N & $\mathbf{\%}$ \\
\hline \multirow{4}{*}{ Fleece cleanliness } & No & 65 & 0 \\
& Clean and dry (0) & 8 & 100 \\
& Dry or damp, light soiling (1) & 51 & 78.46 \\
& Wet, soiled with mud or faces (2) & 6 & 9.23 \\
& Very wet, heavily soiled (3) & 0 & 0 \\
& Filthy (4) & 0 & 0 \\
\hline
\end{tabular}

As shown in Table 4, the most often observed lesions were on the face/muzzle $(32.31 \%)$, legs $(29.23 \%)$ and head/neck $(18.46 \%)$ while one lesion was found on the eyes. Ocular discharge and respiratory problems were observed in $16.92 \%(11 / 65)$ 
and $4.62 \%(3 / 65)$ of animals respectively while no sheep presented any signs of anemia. Most of the assessed sheep had a good fleece quality 84.62\% (55/65) (Table 4). In ten sheep (15.38\%) mild mastitis and/or minor lesions were documented, while minor lameness was recorded in 7.69\% (5/65) of animals. Most of the assessed sheep $90.76 \%(59 / 65)$ had an undocked tail (Table 4).

Table 4. Results of "good health"

\begin{tabular}{|c|c|c|c|}
\hline \multirow{2}{*}{ Welfare Indicator } & & \multicolumn{2}{|c|}{ Sheep $(n=65)$} \\
\hline & & $\mathbf{N}$ & $\%$ \\
\hline \multirow{7}{*}{ Lesions } & Ears & 9 & 13.85 \\
\hline & Eyes & 1 & 1.54 \\
\hline & Face/muzzle & 21 & 32.31 \\
\hline & Head/neck & 12 & 18.46 \\
\hline & Body & 4 & 6.15 \\
\hline & Legs & 19 & 29.23 \\
\hline & Udder and teats & 10 & 15.38 \\
\hline \multirow{2}{*}{ Ocular discharge present } & Yes & 11 & 16.92 \\
\hline & No & 54 & 83.07 \\
\hline \multirow{4}{*}{ Mucosa colour } & Not anemic & 65 & 100 \\
\hline & Borderline anemic & 0 & 0 \\
\hline & Anemic & 0 & 0 \\
\hline & Severely anemic & 0 & 0 \\
\hline \multirow{2}{*}{ Respiratory problems present } & Yes & 3 & 4.62 \\
\hline & No & 62 & 95.38 \\
\hline \multirow{3}{*}{ Fleece quality } & Good & 55 & 84.62 \\
\hline & Some loss & 10 & 15.38 \\
\hline & Significant loss & 0 & 0 \\
\hline \multirow{3}{*}{ Mastitis and udder lesions } & None & 55 & 84.62 \\
\hline & $\begin{array}{l}\text { Mild mastitis and/or minor } \\
\text { lesions }\end{array}$ & 10 & 15.38 \\
\hline & Mastitis and/or severe lesions & 0 & 0 \\
\hline \multirow{4}{*}{ Lameness } & Not lame & 60 & 92.31 \\
\hline & Minor lameness & 5 & 7.69 \\
\hline & Lame & 0 & 0 \\
\hline & Severely lame & 0 & 0 \\
\hline
\end{tabular}




\begin{tabular}{lccc} 
& Undocked & 59 & 90.76 \\
Tail length & Docked & 0 & 0 \\
& Short docked & 6 & 9.23 \\
\hline $\mathrm{n}$ - total number of animals; $\mathrm{N}-$ number of animals with positive or negative score of welfare indicators
\end{tabular}

Results regarding the principle "appropriate behavior" are reported in Table 5. All animals showed no signs of social isolation, stereotypes, and excessive itching. On the other side, all sheep showed fear of humans.

Table 5. Results of "appropriate behavior"

\begin{tabular}{llcc}
\hline \multirow{2}{*}{ Welfare Indicator } & \multicolumn{2}{c}{ Sheep $(\mathrm{n}=\mathbf{6 5})$} \\
\cline { 3 - 4 } & & $\mathbf{N}$ & $\mathbf{\%}$ \\
\hline Expression of social behavior & Social isolation & 0 & 0 \\
& Stereotypy & 0 & 0 \\
Expression of other behaviors & Excessive itching & 0 & 0 \\
& Positive & 0 & 0 \\
Human-animal relationship & Negative & 65 & 100 \\
\hline
\end{tabular}

\section{DISCUSSION}

The present screening of autochthonous sheep "Vlašićka pramenka" welfare using animal-based measures provides an overview of the nutritional, health and welfare state of the ewes, as well as evidencing previous or potential welfare concerns.

\section{Good feeding}

In the present study, we observed significant fluctuations in body condition scores between different physiological statuses of ewes where lactating and pregnant ewes were thinner than dry ewes. These results were expected principally due to the inevitable negative energy balance during the hazardous transition period which involves fat and protein reserves mobilization enhanced by the higher needs for thermoregulation in the cold season [9,10]. Also, differences in body condition score might be due to the agonistic behavior of female sheep when resources are limited, and less dominant animals may suffer [11]. According to Munoz et al. [12] animal welfare issues can occur at both high and low body condition, thin sheep face more immediate risks to welfare generally. They have higher feeding motivation than ewes with higher body condition score, have reduced ability to adapt to cold challenges [13] and are at greater risk of developing pregnancy toxemia [14]. Morgan-Davies et al. [15] found that too lean and too fat body condition have an unfavorable effect on the incidence of abortions and ewe survival under extensive conditions. The period of pregnancy and lactation of 
ewes is a physiological process characterized by a drastic increase in energy and oxygen demands [16], thus feeding the ewe appropriately is crucial for health, welfare and production performances. Efficiently functioning teeth are essential for maintaining good sheep health as incisors wear, damage and loss have been shown to affect the feed intake of sheep leading to reduction in body weight and milk production [17].

\section{Good housing}

In extensive sheep farming, animals can face different welfare issues such us variable climate and availability of adequate or suitable nutrition [18]. Coat cleanliness can provide information on whether sheep have been forced to lie in wet or muddy areas and may be influenced by immediate environmental conditions [6]. In this study, the high percentage of dry or damp, light soiling fleece on the animals is highly related to the extensive sheep farming, winter and no provision of shelter and bedding. Being forced to lie on wet or dirty ground affects the comfort of the sheep. Sheep prefer to rest on soft dry flooring and such conditions depend on the type and amount of flooring materials [19].

\section{Good health}

Lesions, indicators of welfare criteria "good health ", were found on all parts of the sheep body with a high prevalence on face/muzzle and legs where some loss of fleece was present. This result can be related to the fact that sheep are often foragers, seeking their nutrition mainly from pastures but when the food resources are limited, they suffer lesions and lose fleece by seeking food through shrubs and other vegetation [20].

Ocular discharge and respiratory problems in sheep were present in this study. This result can be related to adverse weather of high winds and driving snow. Infectious keratoconjunctivitis is often associated with cold and harsh weather [21]. Competition at feed troughs and hay racks also increases the rate of spread of eye infection [21].

Damp and dirty environments lead to the spread of specific bacteria which cause painful health problems such as mastitis and lameness [22,23]. In this study, minor lameness and mild mastitis and/or minor lesions were present in five and ten sheep, respectively. Regardless of the cause, lameness and mastitis are a major welfare concern as it is a painful condition which if left untreated can be debilitating for the animal $[23,24]$. On the assessed farm, during the winter the shepherd goes for weeks without seeing individual animals due to the nature of extensive systems i.e. systems which require relatively low human labor input and the animals spend most of their lives outside [4]. Additionally, some studies suggest that it is often not possible for the farmer in the extensive system to identify and treat health problems easily and quickly as in an intensive system [25-27]. This can lead to animals suffering problems for weeks or months. 
The one most common pain-inducing management procedure used in sheep farming is tail docking which is permitted without the use of anesthetics or analgesics, in many countries. According to the Law on Animal Husbandry in Bosnia and Herzegovina [28], tail docking is a procedure routinely performed on lambs up to five days of age without the use of anesthetics or analgesics. This study found six sheep with a short docked tail. On the assessed farm tail docking was not used as a management tool. Amputating the tails of lambs is performed only if the tail is infected by myiasis, damaged by sharp objects or otherwise.

\section{Good behavior}

Human - animal relationship represents the mutual perception of stockman and animals and is essential for good animal welfare [29]. Regarding to welfare criteria "good human-animal relationship", we found all animals to be fearful. This finding, i.e. a fear response of animals towards humans, indicate an absence of habituation to human contact, or a learned negative association [30]. In extensive management systems, sheep receive only neutral or aversive contact with people, e.g. restraint, shearing or medication administration. Despite the generations of selective breeding sheep one of the most frightening stimuli they experience is humans [31-33] so the quality of human-animal interaction is very important for good animal welfare. That relationship must be built from a series of interaction over weeks or months. Animals showed no signs of social isolation, stereotypes and excessive itching, respectively no signs of behavior disorders. The results point out that under appropriate physical (e.g. resting area, natural shelters from varying climatic extremes, natural springs ) and social living conditions, there is a possibility for expression of the sheep natural behavior.

\section{CONCLUSION}

The results obtained in the present study showed that extensive systems of management have advantages and disadvantages in terms of animal welfare. This study confirms that there are welfare issues related to measures of all principles. Providing appropriate nutrition and care to the pregnant ewe is an important human intervention in extensive systems. Other actions include treatment of lameness and mastitis, providing adequate physical living condition (e.g. artificial shelter from varying climatic extremes to keep the wool dry and clean) and improve the human-animal relationship with positive interactions. This fast screening assessment of sheep welfare can be a valuable instrument to help farmers to improve animal welfare, meeting the current societal demands. 


\section{Authors' contributions}

NK designed investigation, interpreted the results and wrote the paper. KP performed investigation and co-wrote the paper. VM and ZB performed the statistical anaylsis, analyzed the data and reviewed the manuscript. TR, Ž D, TR and JLj helped performed analysis and co-wrote the paper. All authors read and approved the final manuscript.

\section{Declaration of conflicting interests}

The author(s) declared no potential conflicts of interest with respect to the research, authorship, and/or publication of this article.

\section{REFERENCES}

1. EFSA Panel on Animal Health and Welfare (AHAW): Statement on the use of animalbased measures to assess the welfare of animals. EFSA Journal 2012, 10(6): 2767, 29.

2. FAO STATISTICAL YEAR BOOK (FAOSTAT). World food and agriculture. Rome, 2019. Production of sheep in the world. [http://www.fao.org/faostat/en/\#data/QA/visualize].

3. EFSA Panel on Animal Health and Welfare: Scientific Opinion on the welfare risks related to the farming of sheep for wool, meat and milk production. EFSA Journal 2014, 12:1-128.

4. Morris S: Overview of sheep production systems. In: Ferguson D, Lee C, Fisher A, editors. Advances in sheep welfare. 1st edition. Woodhead Publishing; 2017, 19-33.

5. Goddard P, Waterhouse T, Dwyer C, Stott A: The perception of the welfare of sheep in extensive systems. Small Rumin Res 2006, 62: 215-225.

6. Richmond SE, Wemelsfelder F, de Heredia IB, Ruiz R, Canali E, Dwyer CM: Evaluation of Animal-Based Indicators to Be Used in a Welfare Assessment Protocol for Sheep. Front Vet Sci 2017, 4:210.

7. Važić B, Rogić B, Drinić M, Savić N: Morphometric similarities and differences between tree genotype of pramenka sheep from central Bosnia. Biotechnol Anim Husb 2017, 33: 291-298.

8. AWIN welfare assessment protocol for sheep. DOI: 10.13130/AWIN_SHEEP_2015

9. Pulina G, Bencini R: Dairy Sheep Nutrition. CABI Publishing, Cambridge, Massachusetts; 2004, 222.

10. Everett-Hincks JM, Blair HT, Stafford KJ, Lopez-Villalobos N, Kenyon PR, Morris ST: The effect of pasture allowance during pregnancy on maternal behavior and lamb rearing performance in highly fecund ewes. Livest Prod Sci 2005 97: 253-266.

11. Dwyer C: The behaviour of sheep and goats. In: Per Jensen. The Ethology of Domestic Animals, 3rd edition: an Introductory Text, CABI Publishing, United Kingdom; 2017, 199214.

12. Munoz CA, Campbell AJD, Hemsworth PH, Doyle RE: Evaluating the welfare of extensively managed sheep. PLoS One 2019, 14(6): e0218603.

13. Verbeek E, Oliver MH, Waas JR, McLeay LM, Blache D, Matthews LR: Reduced cortisol and metabolic responses of thin ewes to an acute cold challenge in mid-pregnancy: implications for animal physiology and welfare. PLoS One 2012, 7: e37315. 
14. Caldeira RM, Belo AT, Santos CC, Vazques MI, Portugal A V: The effect of body condition score on blood metabolites and hormonal profiles in ewes hormonal profiles in ewes. Small Rumin Res 2007, 68: 233-241.

15. Morgan-Davies C, Waterhouse A, Pollock ML, and Milner JM: Body condition score as indicator of ewe survival under extensive conditions. Anim Welf 2008, 17: 71-77.

16. Mutinati M, Piccinno M, Roncetti M, Campanile D, Rizzo A, Sciorsci RL: Oxidative stress during pregnancy in the sheep. Review article. Reprod Domest Anim 2013, 48:353-357.

17. McGregor BA: Incisor development, wear and loss in sheep and their impacton ewe production, longevity and economics: A review. Small Rumin 2011, 95: 79-87.

18. Waterhouse A: Animal welfare and sustainability of production under extensive systems A European perspective. Appl Anim Behav Sci 1996, 49: 29-40

19. Færevik G, Andersen IL, Bøe KE: Preferences of sheep for different types of pen flooring. Appl Anim Behav Sci 2005, 90: 265-276.

20. Vučinić M: Ponašanje, dobrobit i zaštita životinja VKS, Beograd, 2004, 388.

21. Hosie BD: Infectious Keratoconjunctivitis. Aitken ID, ed. Diseases of Sheep: Blackwell Publishing; 2007, 342-345.

22. Schreiner D, Ruegg PL: Relationship between udder and leg hygiene scores and subclinical mastitis. J Dairy Sci 2003, 86: 3460-3465.

23. Winter AC: Lameness in sheep. Small Rumin Res 2008, 76: 149-153.

24. Fitzpatrick J, Scott M, Nolan A: Assessment of pain and welfare in sheep. Small Rumin Res 2006, 62: 55-61.

25. Dwyer CM, Lawrence AB: The Welfare of Sheep, in: Dwyer, C.M. (Ed.): The Welfare of Sheep. Springer Science and Business Media BV; 2008, 1-40.

26. Goddard P: Welfare assessment in sheep In Practice 2011, 33: 508-516.

27. Fragkou I, Boscos CM, Fthenakis GC: Diagnosis of clinical or subclinical mastitis in ewes. Small Rumin Res 2014; 118: 86-92.

28. Law on Animal Husbandry in Bosnia and Herzegovina ("Sl. novine FBiH”, 66, 28 Avgust 2013)

29. Hemsworth P: Human-animal interactions in livestock production. Appl Anim Behav Sci 2003, 81: 185-198.

30. Boivin X, Lensink J, Tallet C, Veissier I: Stockmanship and farm animal welfare. Anim Welf 2003, 12: 479-492.

31. Hemsworth PH, Coleman GJ: Improving the attitude and behaviour of stockpersons towards pigs and the consequences on the behaviour and reproductive performance of commercial pigs. Appl Anim Behav Sci 1994, 39, 349-362.

32. Boissy A, Bouissou M: Assessment of individual differences in behavioural reactions of heifers exposed to various fear-eliciting situations. Appl Anim Behav Sci 1995, 46: 17-31.

33. Waiblinger S, Boivin X, Pedersen V, Tosi M, Janczak A, Visser E, Jones R: Assessing the human-animal relationship in farmed species: A critical review. Appl Anim Behav Sci 2006, 101: 185-242. 


\title{
PROCENA DOBROBITI AUTOHTONE RASE OVCE VLAŠIĆKA PRAMENKA U EKSTENZIVNIM USLOVIMA GAJENJA NA OSNOVU DIREKTNIH POKAZATELJA
}

\author{
NENADOVIĆ Katarina, KARAĆ Petar, VUČINIĆ Marijana, \\ TEODOROVIĆ Radislava, ŽIVANOV Dragan, TRAILOVIĆ Ružica, \\ BECKEI Zsolt, JANKOVIĆ Ljiljana
}

U regiji Balkana, stanje dobrobiti ovaca je slabo poznato. Na osnovu toga, procena dobrobiti ovaca je veoma bitna za indetifikaciju njihovih zdravstvenih problema kao i poremećaja ponašanja, zajedno sa nedostacima prisutnim u smeštajnom prostoru. Studija je sprovedena u toku zimskog perioda na farmi od 220 ovaca autohtone rase Vlašićka pramenka koja se uzgaja ekstenzivno u planinskom predelu Bosne i Hercegoven. Ispitano je 65 ženskih grla starih od 2 do 4 godine. Ocena dobrobiti urađena je po metodologiji AWIN protokola za ocenu dobrobiti ovaca. Autori su pronašli sledeće probleme: ovce u zasušenju su bile značajno gojaznije $(\mathrm{p}<0,001)$ u odnosu na gravidne i ovce u laktaciji; 42,11\% gravidnih ovaca je bilo mršavo dok je 31,25\% ovaca u zasušenju bilo gojazno; većina ispitanih životinja (63,08\%) posedovala je suvu, ili vlažnu i malo zaprljanu vunu; kod 32,31\% životinja su utvrđene lezije na njušci dok su iscedak iz oka, respiratorni problem, blagi mastitis i blaga hromost ustanovljeni kod 16,92 \%, 4,62\%, 15,38\% i 7,69\%. Kod svih životinja je test prilaženja čoveku bio negativan. Primenom ove metodologije mogu se otkriti postojeće probleme koji se odnose na stanje dobrobiti ovaca i na taj način se mogu unaprediti određeni segmenti u proizvodnom ciklusu. Ocena dobrobiti na farmama se preporučuje za naglašavanje ključnih tačaka u poboljšanju dobrobiti ovaca u zemljama Balkana. 